\title{
Protein kinase CK2 $\alpha$ is overexpressed in colorectal cancer and modulates cell proliferation and invasion via regulating EMT-related genes
}

\author{
Jinjin Zou ${ }^{1}$, Hesan Luo ${ }^{1}$, Qin Zeng ${ }^{1}$, Zhongyi Dong ${ }^{1}$, Dehua Wu ${ }^{1 *}$ and Li Liư ${ }^{2^{*}}$
}

\begin{abstract}
Background: Protein kinase CK2 is a highly conserved, ubiquitous protein serine/threonine kinase that phosphorylates many substrates and has a global role in numerous biological and pathological processes. Overexpression of the protein kinase CK2 $\alpha$ subunit $(C K 2 \alpha)$ has been associated with the malignant transformation of several tissues, with not nearly as much focus on the role of CK2 $\alpha$ in colorectal cancer (CRC). The aims of this study are to investigate the function and regulatory mechanism of CK2 $\alpha$ in CRC development.

Methods: Expression levels of CK2 $\alpha$ were analyzed in 144 patients (104 with CRC and 40 with colorectal adenoma) by immunohistochemistry. Proliferation, senescence, motility and invasion assays as well as immunofluorescence staining and western blots were performed to assess the effect of CK2 $\alpha$ in CRC.

Results: The immunohistochemical expression of nuclear CK2 $\alpha$ was stronger in tumor tissues than in adenomas and normal colorectal tissues. Suppression of CK2 $\alpha$ by small-interfering RNA or the CK2 $\alpha$ activity inhibitor emodin inhibited proliferation of CRC cells, caused G0/G1 phase arrest, induced cell senescence, elevated the expression of p53/p21 and decreased the expression of C-myc. We also found that knockdown of CK2 $\alpha$ suppressed cell motility and invasion. Significantly, CK2 $\alpha$ inhibition resulted in $\beta$-catenin transactivation, decreased the expression levels of vimentin and the transcription factors snail 1 and smad2/3, and increased the expression of E-cadherin, suggesting that CK2 $\alpha$ regulates the epithelial-mesenchymal transition (EMT) process in cancer cells.
\end{abstract}

Conclusions: Our results indicate that CK2 $\alpha$ plays an essential role in the development of CRC, and inhibition of CK2 $\alpha$ may serve as a promising therapeutic strategy for human CRC.

\section{Introduction}

Colorectal cancer (CRC) is the second-most common cause of cancer death in the West [1] and its incidence in China has increased rapidly during the past few decades [2]. Colorectal cancers can be divided into tumors exhibiting chromosomal instability and tumors exhibiting microsatellite instability [3,4]. In the last few years, molecular biology advances have led to a growing knowledge of the mechanisms underlying CRC development, including the mutational activation of oncogenes

\footnotetext{
* Correspondence: wudehua.gd@gmail.com; liliu.gd@gmail.com 'Department of Radiation Oncology, Nanfang Hospital, Southern Medical University, Guangzhou 510515, Guangdong Province, China

${ }^{2}$ Hepatology Unit and Department of Infectious Diseases, Nanfang Hospital, Southern Medical University, Guangzhou 510515, Guangdong Province, China

Full list of author information is available at the end of the article
}

and alteration of several tumor suppressor genes, such as adenomatous polyposis coli (APC), deleted in colorectal cancer (DCC) and p53 [5-8]. However, molecular markers that indicate the occurrence and development of CRC are still needed.

Protein kinase CK2 (formerly casein kinase II) has traditionally been classified as a messenger-independent protein serine/threonine kinase that is typically found in tetrameric complexes consisting of two catalytic ( $\alpha$ and/ or $\alpha$ ) subunits and two regulatory $\beta$ subunits [9]. To date, more than 300 CK2 substrates have been identified; one third of these are implicated in gene expression and protein synthesis as translational elements [10]. CK2 $\alpha$ knockout mice are not viable because of defects in heart and neural tube development [11]. The disruption of CK2 $\alpha$ expression in Saccharomyces cerevisiae and knockout of CK2 $\beta$ in mice are lethal events, indicating the

\section{Biomed Central}


importance of CK2 in the maintenance of cell viability during the normal cell life and embryogenesis [12,13]. CK $2 \alpha$ also participates in the regulation of various cell cycle stages, presumably through phosphorylation of the proteins associated with cell cycle progression [14]. Furthermore, CK2 involvement has been found in chromatin remodeling as well as protein transcription, translation, and degradation [15-17]. Recent studies suggest that CK2 creates an environment that is favorable for the development of the tumor phenotype [18].

In the present study, we assessed CK $2 \alpha$ expression in colorectal cancer, adenoma, and normal colorectal epithelium and found CK $2 \alpha$ involvement in CRC tumorigenesis. Moreover, the role of CK $2 \alpha$ in cell proliferation, senescence, motility and invasion was examined in CRC cell lines that were subjected to CK2 $\alpha$ knockdown or to the CK2 $\alpha$ activity inhibitor emodin. Further analysis was conducted to elucidate the mechanisms of CK2 $\alpha$ involvement in the occurrence and development of CRC.

\section{Materials and methods}

\section{Patient characteristics}

We obtained paraffin-embedded samples of 104 CRCs and 40 adenomas that were diagnosed on the basis of histological and clinical findings at the Nanfang Hospital between 2005 and 2007. Prior patient consent and approval from the Institute Research Ethics Committee were obtained before we used these clinical materials for research purposes. The CRC stage was defined according to the AJCC classification. The clinical characteristics of the patients with CRC are summarized in detail in Table 1 . The tumors taken from the adenoma group (20 males and 20 females; age, 28 - 73 years [mean: 50.5]) consisted of 3 serrate adenomas, 22 canalicular adenomas, 9 villous adenomas, and 6 tubulovillous adenomas.

\section{Immunohistochemistry}

Immunohistochemical staining was performed using a Dako Envision System (Dako, Carpinteria, CA, USA) following the manufacturer's recommended protocol. Briefly, all paraffin sections, $4 \mu \mathrm{m}$ in thickness, were heated for $1 \mathrm{~h}$ at $65^{\circ} \mathrm{C}$, deparaffinized with xylene, rehydrated through a graded series of ethanol/distilled water concentrations, submerged in EDTA buffer ( $\mathrm{pH}$ 8.0), heated in a microwave for antigen retrieval, treated with $0.3 \% \mathrm{H}_{2} \mathrm{O}_{2}$ for 15 min to block the endogenous peroxidase, incubated overnight with rabbit monoclonal antiCK2 $\alpha$ antibody (1:50; Abcam, Cambridge, UK) at $4{ }^{\circ} \mathrm{C}$, washed, incubated with horseradish peroxidase (HRP) at $4^{\circ} \mathrm{C}$ for $30 \mathrm{~min}$, and visualized with diaminobenzidine (DAB). For negative controls, the antibody was replaced by normal goat serum.
Table 1 Clinicopathological characteristics of the 104 patients and expression of CK2 $\alpha$ in CRC.

\begin{tabular}{|c|c|}
\hline & N (\%) \\
\hline \multicolumn{2}{|l|}{ Gender } \\
\hline Male & $56(53.8)$ \\
\hline Female & $48(46.2)$ \\
\hline \multicolumn{2}{|l|}{ Age } \\
\hline$\geq 55$ & $54(51.9)$ \\
\hline$<55$ & $50(48.1)$ \\
\hline \multicolumn{2}{|l|}{ Tumor location } \\
\hline Colon & $53(51.0)$ \\
\hline Rectum & $51(49.0)$ \\
\hline \multicolumn{2}{|l|}{ T stage } \\
\hline $\mathrm{T} 1-\mathrm{T} 2$ & $49(47.1)$ \\
\hline T3-T4 & $55(52.9)$ \\
\hline \multicolumn{2}{|l|}{ N stage } \\
\hline $\mathrm{Nx}-0$ & $55(52.9)$ \\
\hline $\mathrm{N} 1-2$ & $49(47.1)$ \\
\hline \multicolumn{2}{|l|}{ M stage } \\
\hline MO & $60(57.7)$ \\
\hline M1 & $44(42.3)$ \\
\hline \multicolumn{2}{|l|}{ TNM stage } \\
\hline$|-| \mid$ & $30(28.8)$ \\
\hline III-IV & $74(71.2)$ \\
\hline \multicolumn{2}{|c|}{ Degree of differentiation } \\
\hline Well & $35(33.7)$ \\
\hline Moderately & $45(43.3)$ \\
\hline Poorly & $24(23.0)$ \\
\hline \multicolumn{2}{|l|}{ Expression of CK2 $\alpha$} \\
\hline Low expression & $43(41.3)$ \\
\hline High expression & $61(58.7)$ \\
\hline
\end{tabular}

\section{Evaluation of staining}

The immunohistochemically stained tissue sections were scored separately by two pathologists who were blinded to the clinical parameters. For assessment of CK $2 \alpha$, the entire tissue section was scanned before assigning the scores. The staining intensity was scored as 0 (negative), 1 (weak), 2 (medium), or 3 (strong). The extent of staining was scored as 0 (0\%), 1 (1 - 25\%), 2 (26 - 50\%), 3 (51 - 75\%), or 4 (76 - 100\%), according to the percentages of the positive staining areas relative to the entire carcinoma-involved area or, for the normal samples, the entire section. The sum of the intensity and extent scores was used as the final CK2 $\alpha$ staining score $(0-7)$. This relatively simple, reproducible scoring method gives highly concordant results between independent evaluators and has been used in previous studies $[19,20]$. For the purpose of statistical evaluation, tumors with a final staining score of $\geq 3$ were considered to be positive for CK $2 \alpha$. 


\section{Cell lines and culture conditions}

The human colorectal cancer cell lines LoVo, SW480, HT29, HCT116 and LS174T were maintained in RPMI 1640 (Gibco, Grand Island, NY, USA) supplemented with $10 \%$ fetal bovine serum at $37^{\circ} \mathrm{C}$ in a $5 \% \mathrm{CO}_{2}$ humidified incubator.

\section{CK2 $\alpha$ SiRNA}

Cells were seeded onto a six-well plate $16 \mathrm{~h}$ before transfection. In each well, $100 \mathrm{pmol}$ of CK $2 \alpha$ siRNA (CSNK2A1 siRNA: 5'-GAUGACUACCAGCUGGUUC3') or scramble sequences and $5 \mu$ l of Lipofectamine 2000 (Invitrogen, Carlsbad, CA, USA) were added to Opti-MEM medium and mixed gently. The plate was incubated for $48 \mathrm{~h}$ until it was ready for further assay.

\section{Western blot analysis}

Cells and tissues were washed twice with cold phosphatebuffered saline (PBS) and lysed on ice in RIPA buffer $(1 \times$ PBS, 1\% NP40, 0.1\% SDS, 5 mM EDTA, 0.5\% sodium deoxycholate, and $1 \mathrm{mM}$ sodium orthovanadate) with protease inhibitors. Whole extracts were resolved on $10 \%$ SDS polyacrylamide gels and electrotransferred to polyvinylidene fluoride (PVDF; Immobilon P; Millipore, Bedford, MA, USA) membranes, which were then blocked in $5 \%$ non-fat dry milk in Tris-buffered saline (TBST) (pH 7.5; $100 \mathrm{mM} \mathrm{NaCl}, 50 \mathrm{mM}$ Tris, and $0.1 \%$ Tween-20) and immunoblotted with rabbit anti-CK2 $\alpha$ monoclonal antibody (1:800; Abcam), mouse anti-E-cadherin (1:500; Santa Cruz Biotechnology, Santa Cruz, CA, USA), anti- $\beta$ catenin (1:500; Santa Cruz), mouse anti-vimentin (1:500; Santa Cruz), mouse anti-C-myc (1:200; Santa Cruz), mouse anti-p53 (1:200; Santa Cruz), mouse anti-p21 (1:200; Santa Cruz), mouse anti-GAPDH monoclonal antibody (1:1000; Santa Cruz), rabbit anti-snail1 (1:750; Bioworld Technology, St. Louis Park, MN, USA), or rabbit anti-smad2/3 (1:750; Cell Signaling Technology, Beverly, MA, USA) overnight at $4^{\circ} \mathrm{C}$, followed by their respective secondary antibodies conjugated to horseradish peroxidase (HRP). The signals were detected by enhanced chemiluminescence (ECL; Pierce, Rockford, IL, USA). The images were analyzed by Image J software.

\section{Immunofluorescence staining}

Cells were cultured on coverslips overnight, fixed with $4 \%$ paraformaldehyde for $20 \mathrm{~min}$, treated with $0.25 \%$ Triton X-100 for 10 min, blocked in 10\% normal blocking serum at room temperature for $10 \mathrm{~min}$, incubated with mouse monoclonal anti- $\beta$-catenin (1:50; Santa Cruz) at $4^{\circ} \mathrm{C}$ overnight, washed with PBS three times, incubated with TRITC (teramethylrhodamine-6-thiocarbamoyl)-conjugated anti-mouse secondary antibodies (Invitrogen, Carlsbad, CA, USA) for $30 \mathrm{~min}$ at room temperature, and stained with 4,6-diamidino-2-phenylindole (DAPI; Invitrogen).

\section{In vitro cell growth assay}

The cells were prepared at a concentration of $1 \times 10^{4}$ cells $/ \mathrm{ml}$. Aliquots $(100 \mu \mathrm{l})$ were dispensed into 96 -well microtiter plates. The cells were incubated for $1,2,3,4$, 5 , or 6 days, and the 3-(4,5-dimethylthiazol-2-yl)-2,5diphenyltetrazolium bromide (MTT) assay was performed by adding $20 \mu \mathrm{l}$ of MTT $(5 \mathrm{mg} / \mathrm{ml}$; Promega, Madison, WI, USA) for 4 hours. When the MTT incubation was complete, the supernatants were removed. Dimethyl sulfoxide (Sigma, St. Louis, MO, USA) was added to each well $(150 \mu \mathrm{l})$. Fifteen minutes later, the absorbance (OD) of each well was measured with a microplate reader set at $570 \mathrm{~nm}$.

\section{Colony formation assay}

Approximately $1 \times 10^{2}$ cells from each treatment group were seeded in triplicate wells $(3 \mathrm{~cm}$ in diameter) of a six-well culture plate, incubated at $37^{\circ} \mathrm{C}$ for 12 days, washed twice with PBS, and stained with Giemsa solution. The number of colonies containing more than 50 cells was counted under a microscope.

\section{Senescence-associated $\beta$-galactosidase staining}

Cells were seeded in triplicate on 12 -well plates, fixed with $4 \%$ paraformaldehyde for $30 \mathrm{~min}$, and stained with senescence-associated $\beta$-galactosidase (SA- $\beta$-gal) solution (Invitrogen). The numbers of blue-stained (SA- $\beta$ gal-positive) and total cells were manually counted under a microscope and averaged for three regions per sample well. The percentage of SA- $\beta$-gal-positive cells was calculated accordingly.

\section{Flow cytometry assay}

Cells were harvested at an exponential growth phase, and single-cell suspensions containing $1 \times 10^{6}$ cells were fixed with $70 \%$ alcohol. The cell cycle was monitored using propidium iodide (PI) staining of nuclei. The fluorescence of DNA-bound PI in cells was measured with a FACScan flow cytometer (BD Biosciences), and the results were analyzed with ModFit 3.0 software (Verity Software House, Topsham, ME).

\section{Wound migration assay}

Monolayers were wounded by scraping with a $200-\mu \mathrm{l}$ pipette tip. Scratches were monitored for the percentage of wound closure over the next $24 \mathrm{~h}$. The wound was measured in 12 places located at preset distances and averaged. Wound healing was quantified, and statistical analysis was conducted relative to the control siRNA. 


\section{Tumor cell invasion assay}

Warm serum-free medium was added to the top chamber of the cell invasion chamber (Chemicon, Temecula, CA, USA) to rehydrate the ECM layer for $2 \mathrm{~h}$ at room temperature. Tumor cells in serum-free medium (300 $\mu \mathrm{l}$ containing $1 \times 10^{5}$ cells) were added to the top chamber. The bottom chamber was prepared with $10 \%$ FBS as a chemoattractant. After $18 \mathrm{~h}$ of incubation, noninvasive cells were removed with a cotton swab. The cells that had migrated through and adhered to the lower surface of the membrane were fixed with methanol, stained with hematoxylin, and counted under a microscope in five randomly selected fields at $\times 200$ magnifications.

\section{Statistical analysis}

All statistical analyses were carried out using the SPSS statistical software package, version 13.0 (SPSS, Chicago, IL, USA). A chi-squared test was used to analyze the differential expression of CK $2 \alpha$ in colorectal cancers, adenomas and adjacent normal colorectal mucosa. The Mann-Whitney $U$-test and Kruskal-Wallis $H$-test were used to analyze the relationship between CK $2 \alpha$ expression and gender, age, tumor location, degree of differentiation, $\mathrm{T}$ stage, $\mathrm{N}$ stage, $\mathrm{M}$ stage, and clinical stage. Paired $t$-tests, Student's $t$-tests, factorial analysis and one-way ANOVA were used to analyze the findings of the in vitro cell assay. A $P$ value of less than 0.05 was considered statistically significant.

\section{Results}

\section{CK2 $\alpha$ is overexpressed in colorectal cancer}

CK $2 \alpha$ protein expression was analyzed in 144 patients (104 with CRC and 40 with colorectal adenoma). Staining for CK $2 \alpha$ was nearly negative in all of the normal colorectal epithelium samples (Figure 1A), and nuclear staining for CK2 $\alpha$ was extremely weak in only 11 normal colorectal epithelium samples (11 of $86,12.8 \%$ ), positive in 17 of 40 (42.5\%) colorectal adenoma samples (Figure 1B, C), and positive in 61 of 104 (58.7\%) CRC samples (Figure 1D, E, F). CK2 $\alpha$ immunoexpression was much stronger in CRC than in adenomas, while its expression was greater in adenomas than in normal colorectal epithelium $\left(\chi^{2}=42.035, P<0.05\right)$. These data indicate that CK $2 \alpha$ may have a role in the process of CRC tumorigenesis. We also assessed CK2 $\alpha$ expression in 8 normal-CRC tissue pairs by western blot. Similar to the result in our immunohistochemistry assay, CK $2 \alpha$ expression was significantly higher in colorectal tumor tissues than in normal colorectal tissues (Figure 2A, B) $(P<0.01)$. In addition, CK $2 \alpha$ was expressed in five CRC cell lines (Figure 2C).

\section{CK $2 \alpha$ overexpression is correlated with $\mathrm{T}$ classification in colorectal cancer}

Next, we investigated the association between CK $2 \alpha$ expression and the clinicopathological characteristics of CRC cases and found that CK2 $\alpha$ overexpression was significantly associated with $\mathrm{T}$ classification $(P=0.002)$. The expression of the CK2 $\alpha$ protein in CRC in the T3T4 stage was significantly higher than in the T1-T2 stage. However, no significant correlation was found between CK $2 \alpha$ expression and gender, age, degree of differentiation, $\mathrm{N}$ classification, distant metastasis, or location (Table 2) $(P>0.05)$. Because $\mathrm{T}$ describes how far the main (primary) tumor has grown into the wall of the intestine and whether it has grown into nearby areas, we speculated that $\mathrm{CK} 2 \alpha$ may participate in CRC cell invasion.

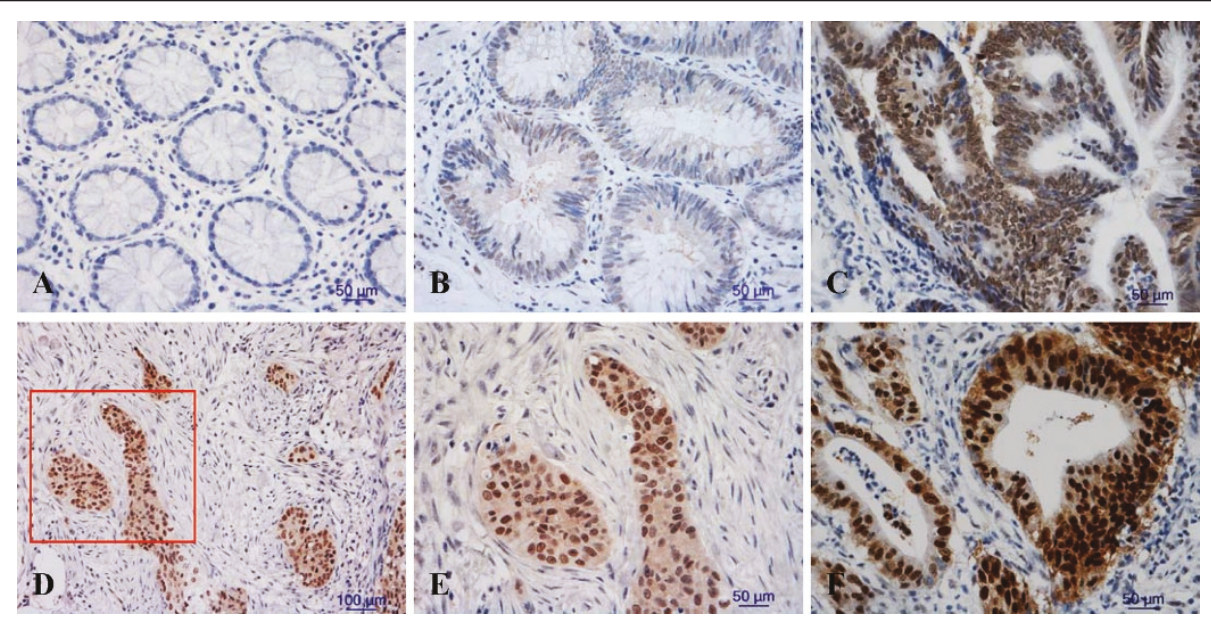

Figure 1 Immunohistochemical detection of CK2 $\alpha$ expression in colorectal cancers, adenomas and adjacent normal colorectal mucosa Staining was (A) negative in normal colorectal epithelium cells, $(B, C)$ weak to moderate in the nuclei of colorectal adenoma cells, (D, E, F) and strong in the nuclei of colorectal cancer cells. (E is a close-up of the inset in D [framed in red]). Original magnification: $\times 200$ (D), $\times 400$ (A, B, C, E, F). 
A
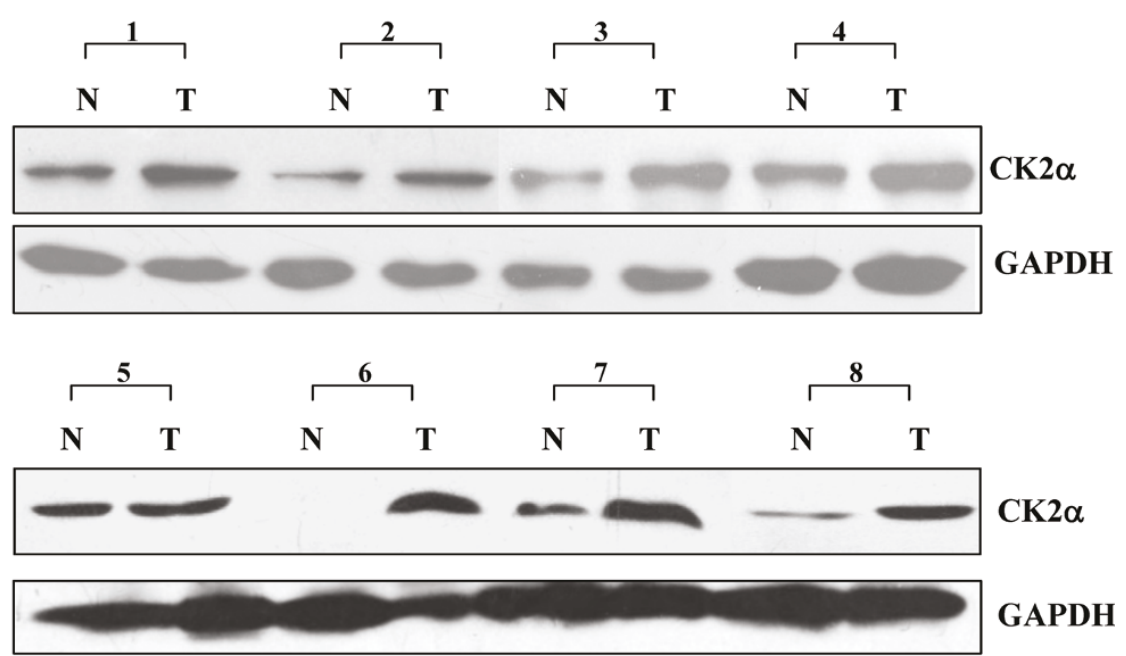

B

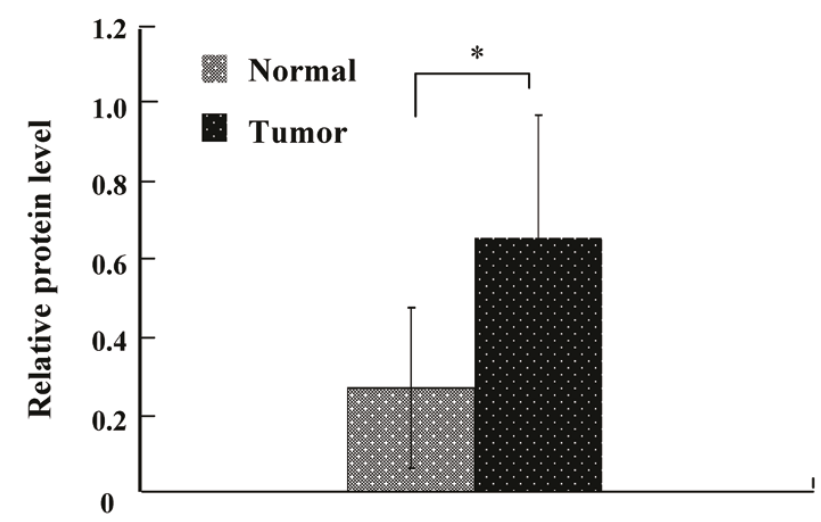

C
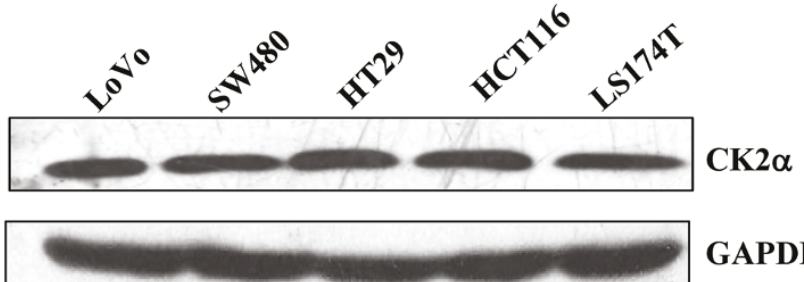

GAPDH

Figure 2 CK2 $\alpha$ protein expression in CRC tissues and cell lines. (A) Western blot analysis of CK2 $\alpha$ expression in eight pairs of CRC tissues and adjacent, normal colorectal mucosa tissues. N: normal colorectal mucosa tissue; T: tumor tissue. (B) Quantitative analysis of CK2 $\alpha$ protein expression in eight pairs of CRC tissues and adjacent normal colorectal mucosa tissues. Columns, mean CK2 $\alpha$ protein level after normalizing the data to GAPDH expression; bars, SD. ${ }^{*} P<0.01$. (C) Western blot was used to detect CK2 $\alpha$ expression in five CRC cell lines. GAPDH expression was used as a loading control.

\section{CK2 $\alpha$ regulates growth, proliferation and senescence of}

\section{CRC cell lines}

Because the process of tumorigenesis is closely correlated with eternal proliferation of tumor cells, we determined whether CK2 $\alpha$ expression plays a role in human CRC cell growth and proliferation using siRNA to knock down CK2 $\alpha$ expression or emodin to inhibit CK2 $\alpha$ activity (Figure 3A). The MTT assay showed that knockdown of CK2 $\alpha$ significantly decreased CRC cell proliferation compared to the control (nonspecific siRNA) $(F=32.854, P<0.01$ for LoVo cells; $F=32.655$,
$P<0.01$ for SW480 cells), and treatment with emodin markedly reduced proliferation $(F=33.290, P<0.01$ for LoVo cells; $F=57.052, P<0.01$ for SW480 cells; Figure $3 \mathrm{~B})$. Furthermore, in the colony formation assay, inhibition of CK2 $\alpha$ expression dramatically decreased the number of CRC colonies $(t=20.252, P<0.01$ for LoVo cells; $t=12.034, P<0.01$ for SW480 cells; Figure $3 C$ ) and promoted CRC cell senescence $(t=43.052, P<$ 0.01 ; Figure $3 \mathrm{D})$. Taken together, the results indicate that CK $2 \alpha$ plays a very important role in human CRC cell proliferation and senescence. CK $2 \alpha$ knockdown or 
Table 2 Correlation between the clinicopathological features and expression of the CK2 $\alpha$ protein.

\begin{tabular}{|c|c|c|c|c|}
\hline \multirow[b]{2}{*}{ Characteristics } & \multirow[b]{2}{*}{$\mathrm{N}$} & \multicolumn{2}{|c|}{ CK2 $\alpha(\%)$} & \multirow[b]{2}{*}{$P$} \\
\hline & & $\begin{array}{c}\text { Low } \\
\text { expression }\end{array}$ & $\begin{array}{l}\text { High } \\
\text { expression }\end{array}$ & \\
\hline Gender & & & & 0.646 \\
\hline Male & 56 & $22(39.3)$ & $34(60.7)$ & \\
\hline Female & 48 & $21(43.8)$ & $27(56.2)$ & \\
\hline Age & & & & 0.897 \\
\hline$\geq 55 y$ & 54 & $22(40.7)$ & $32(59.3)$ & \\
\hline$<55 y$ & 50 & $21(42.0)$ & $29(58.0)$ & \\
\hline Tumor location & & & & 0.554 \\
\hline Colon & 53 & $21(39.6)$ & $32(60.4)$ & \\
\hline Rectum & 51 & $22(43.1)$ & $29(56.9)$ & \\
\hline T stage & & & & $0.002^{*}$ \\
\hline T1-T2 & 49 & $21(42.9)$ & $28(57.1)$ & \\
\hline T3-T4 & 55 & $15(27.2)$ & $40(72.7)$ & \\
\hline $\mathrm{N}$ stage & & & & 0.515 \\
\hline$N x-0$ & 55 & $20(36.4)$ & $35(63.6)$ & \\
\hline $\mathrm{N} 1-2$ & 49 & $23(46.9)$ & $26(53.1)$ & \\
\hline M stage & & & & 0.632 \\
\hline Mo & 60 & $26(43.3)$ & $34(56.7)$ & \\
\hline M1 & 44 & 17 (38.6) & $27(61.4)$ & \\
\hline TNM stage & & & & 0.539 \\
\hline$|-| \mid$ & 30 & $11(36.7)$ & $19(63.7)$ & \\
\hline III-IV & 74 & $32(43.2)$ & $42(56.8)$ & \\
\hline $\begin{array}{l}\text { Degree of } \\
\text { differentiation }\end{array}$ & & & & 0.632 \\
\hline Well & 35 & $13(37.1)$ & $22(62.9)$ & \\
\hline Moderately & 45 & $21(46.7)$ & $24(53.3)$ & \\
\hline Poorly & 24 & $9(37.5)$ & $15(62.5)$ & \\
\hline
\end{tabular}

*Statistically significant difference.

depression visibly inhibited cell proliferation and promoted cell senescence.

After CK $2 \alpha$ knockdown, the percentage of G0/G1 phase cells significantly increased $(t=-9.577, P<0.01)$, and the percent of $\mathrm{S}$ phase cells significantly decreased $(t=8.749, P<0.01$; Figure $4 \mathrm{~A}, \mathrm{~B})$, indicating that CK2 $\alpha$ knockdown induced G0/G1 phase arrest. Moreover, CK $2 \alpha$ knockdown increased endogenous p53 and p21 expression and decreased endogenous $\mathrm{C}$-myc expression (Figure 4C). Thus, it can be inferred that the inhibition of cell proliferation and cell cycle arrest in CK2 $\alpha$ knockdown cells are associated with alterations in p53, p21 and $\mathrm{C}$-myc expression.

\section{CK2 $\alpha$ knockdown inhibits cell migration and invasion}

Migration and matrigel invasion assays were performed to examine the effect of CK2 $\alpha$ on tumor cell migration and invasion, respectively. Knockdown of CK2 $\alpha$ greatly inhibited wound closure $(F=53.517, P<0.01$ for LoVo cells; $F=40.319, P<0.01$ for SW480 cells; Figure $5 \mathrm{~A}$ ) and invasion $(t=5.955, P<0.01$ for LoVo cells; $t=$
4.339, $P<0.05$ for SW480 cells; Figure 5B). Accordingly, CK2 $\alpha$ was positively correlated with CRC cell migration and invasion ability.

\section{CK2 $\alpha$ knockdown reversed nuclear translocation of $\beta$ - catenin and altered the expression of E-cadherin and vimentin, in association with repression of the transcription factors snail 1 and smad2/3 expression}

Knockdown of CK2 $\alpha$ reversed the cytoplasmic-tonuclear transfer of $\beta$-catenin resulted by EGF stimuli (Figure 6A). We also measured the expression levels of EMT-related genes by analyzing western blots. Cells transfected with CK $2 \alpha$ siRNA had dramatically reduced levels of endogenous CK2 $\alpha$ and increased levels of Ecadherin, an epithelial marker; there was no effect on the $\beta$-catenin expression level and a decreased level of vimentin, a mesenchymal marker. In addition, knockdown of CK2 $\alpha$ decreased the expression of the transcription factors snaill and smad2/3 (Figure 6B). The results show that $\mathrm{CK} 2 \alpha$ knockdown represses EMT in CRC. We also treated cells with emodin and found that CK2 $\alpha$ activity, but not protein expression, was affected. Emodin increased the expression of E-cadherin, had no effect on the expression of $\beta$-catenin, and decreased the expression of vimentin in a concentration-dependent manner (Figure 6C). Thus, depression of CK2 $\alpha$ activity can inhibit the expression of EMT-related genes, suggesting that an increase in $\mathrm{CK} 2 \alpha$ protein or activity may facilitate EMT and thus plays an important role in colorectal cancer invasion.

\section{Discussion}

In this present study, we assessed CK2 $\alpha$ expression in colorectal cancer, adenoma and normal colorectal epithelium and found that $\mathrm{CK} 2 \alpha$ was overexpressed in CRC. Consistent with a recent study by Lin et al. [21], our findings convincingly demonstrate that CK $2 \alpha$ was significantly upregulated in CRC. Our study further showed that CK $2 \alpha$ protein expression levels were increased in both CRC and colorectal adenoma, and CK2 $\alpha$ expression was much higher in CRC than in adenoma, suggesting that $\mathrm{CK} 2 \alpha$ may be involved in the progression from adenoma to CRC. In addition, we found that $C K 2 \alpha$ overexpression was only associated with $\mathrm{T}$ classification, but there were no significant correlations with other clinical characteristics, possibly due to our relatively small sample size.

Several studies have shown that the dysregulation of CK2 enhances tumor cell survival [22,23], but the function of CK2 $\alpha$ in CRC is less well known. In our study, we assessed the role of CK2 $\alpha$ in the biological behavior of CRC. As in a recent study [21], we found that CK2 $\alpha$ knockdown inhibited cell proliferation and colon formation in other CRC cell lines. Moreover, for the first 
A

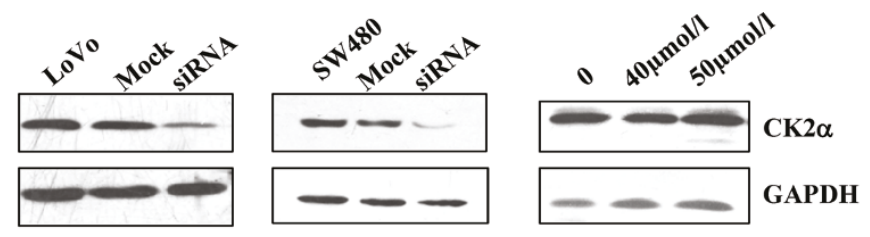

B
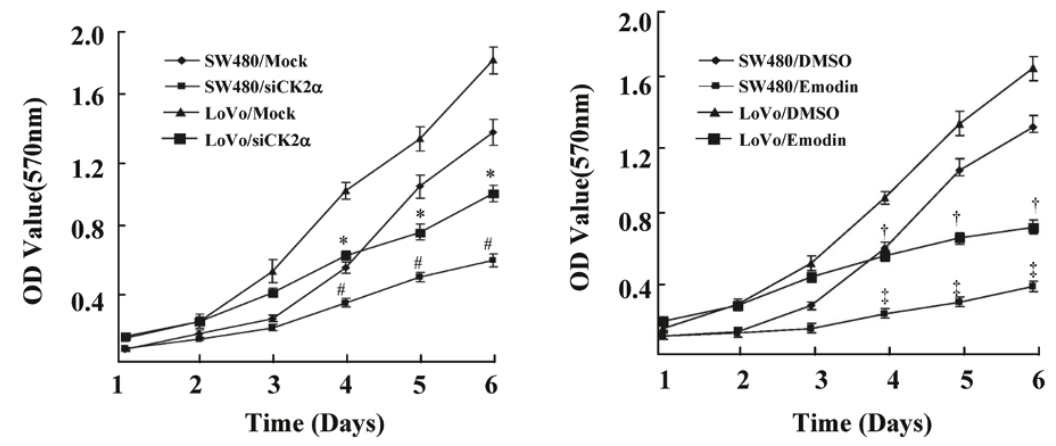

C

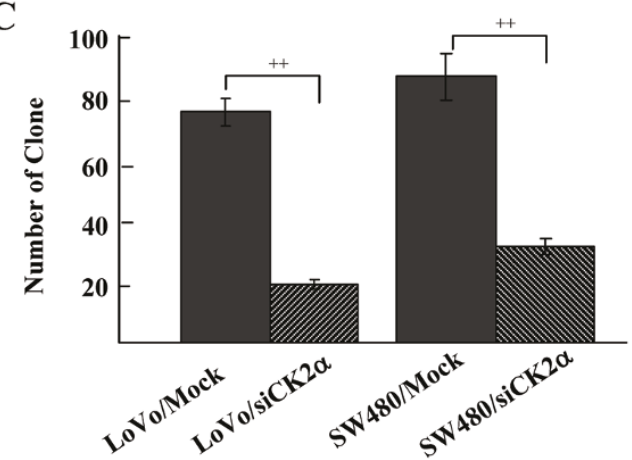

D

LoVo

LoVo/Mock

LoVo/siCK2 $\alpha$
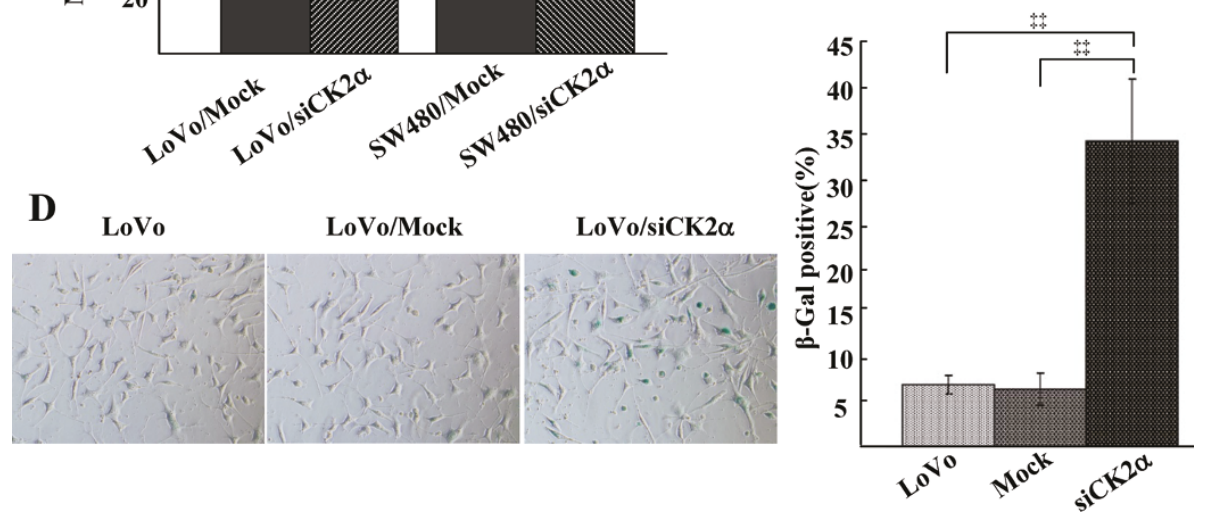

Figure 3 Knockdown of CK2 $\alpha$ inhibited cell proliferation and promoted cell senescence of CRC cell lines. (A) Western blot analysis of CK2 $\alpha$ protein in lysates of cells transfected with a specific CK2 $\alpha$ siRNA or treated with emodin. GAPDH expression was used as a loading control. (B) MTT assay of the proliferating cells transfected with a CK2 $\alpha$-specific siRNA or a nonspecific siRNA and treated with emodin. Points, mean of three independent experiments; bars, SD. ${ }^{*} P<0.01$ versus LoVo/Mock; $\# P<0.01$ versus SW480/Mock; $+P<0.01$ versus LoVo/DMSO; $¥ P$ $<0.01$ versus SW480/DMSO. (C) The number of colonies formed from cells transfected with CK2 $\alpha$ siRNA. Colonies were stained with crystal violet and counted. Columns, mean of three independent experiments; bars, SD. $++P<0.01$. (D) The number of SA- $\beta$-gal-positive cells (green) $48 \mathrm{~h}$ after transfection with CK2 $\alpha$ siRNA. Cells were stained with SA- $\beta$-gal staining solution. Columns, mean of three independent experiments; bars, SD. $\neq \neq P<0.01$

time, we observed that, in CRC, CK2 $\alpha$ knockdown induces G0/G1 phase arrest and promotes cell senescence. Similarly, inhibition of CK2 $\alpha$ activity by emodin induced proliferation repression. In addition, CK2 $\alpha$ knockdown increased p53/p21 expression and decreased $\mathrm{C}$-myc expression. Accordingly, our results demonstrate that CK2 $\alpha$ has multiple roles in the biological behavior of CRC, which is mediated by the regulation of oncogenes and anti-oncogenes, including $\mathrm{C}$-myc, p53 and $\mathrm{p} 21$.

In our study, CK2 $\alpha$ was found to have an important role in the biological behavior of CRC. Therefore, it is vitally important to investigate the potential regulatory mechanisms of CK $2 \alpha$. However, the regulatory mechanism of CK $2 \alpha$ in contributing to the development of CRC is still unknown. The progression from normal 
A

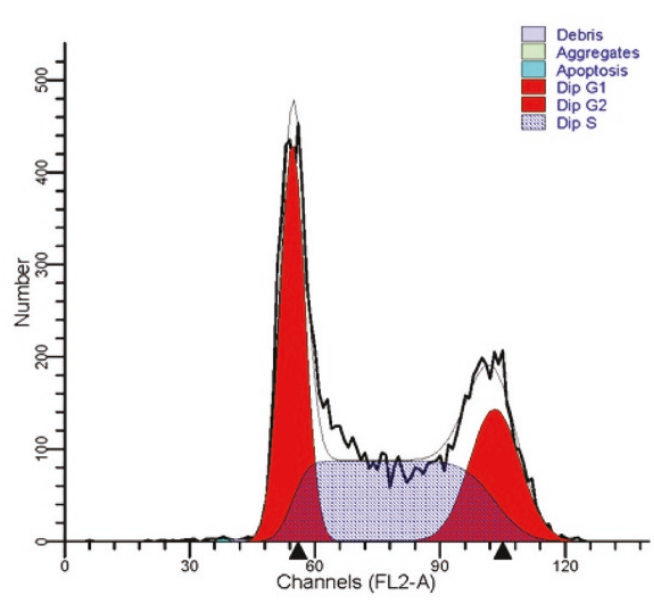

Mock

B

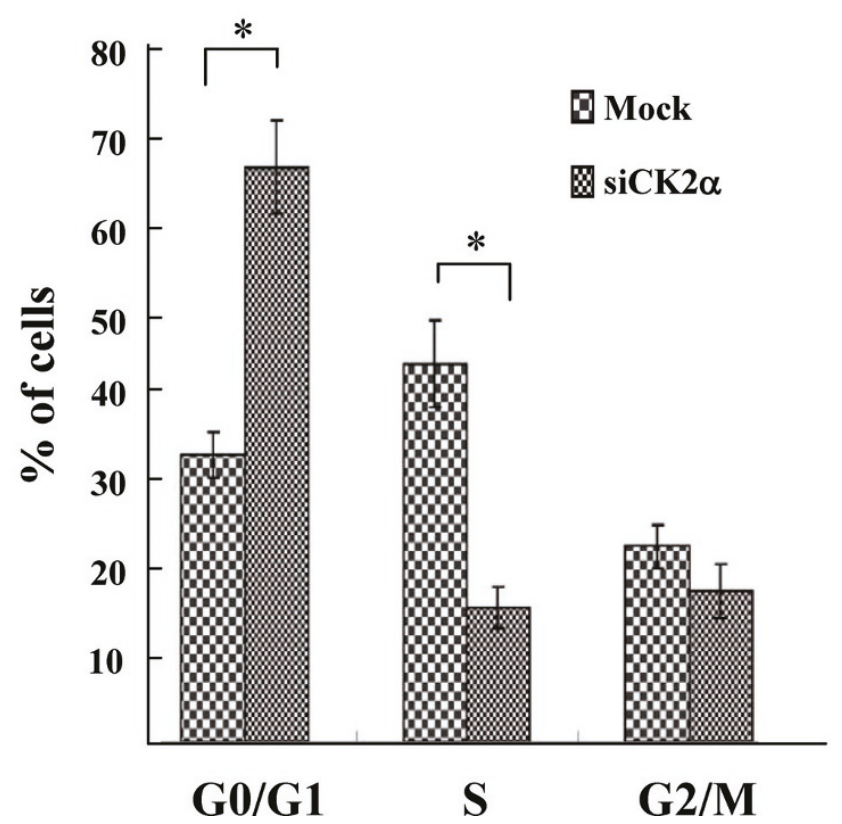

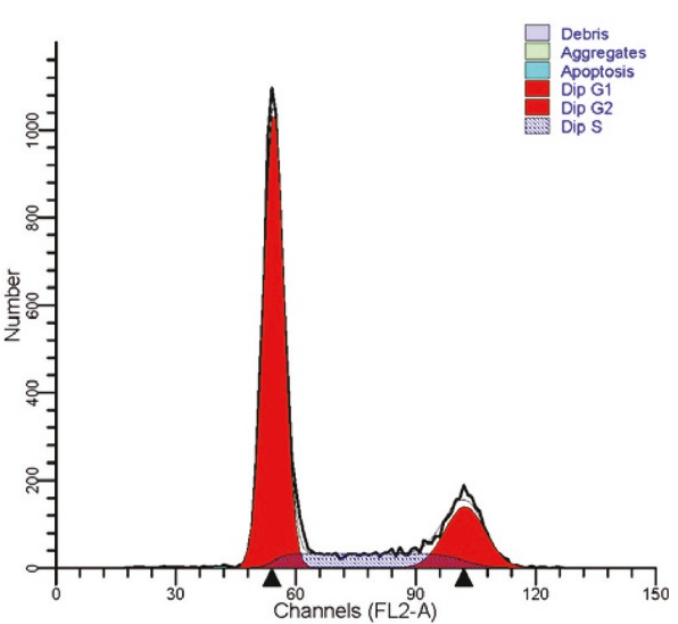

$\operatorname{siCK} 2 \alpha$
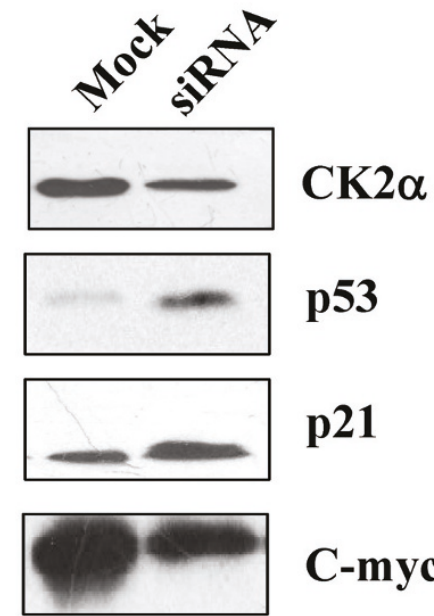

C-myc

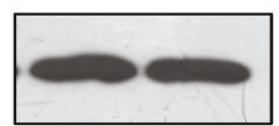

GAPDH

Figure 4 CK2 $\alpha$ inhibition induced G0/G1 phase arrest. (A) LoVo cells were transfected with CK2 $\alpha$-specific siRNA or nonspecific siRNA, stained with propidium iodide (PI), and monitored by flow cytometry to determine the cell cycle phase distribution. (B) Comparison of the percentage of cells in each phase of the cell cycle between LoVo cells transfected with CK2 $\alpha$-specific siRNA and nonspecific siRNA. Columns, mean of three independent experiments; bars, SD. ${ }^{*} P<0.01$. (C) CK2 $\alpha$, p53, p21, C-myc and GAPDH expression in cells transfected with CK2 $\alpha$-specific siRNA was detected by western blot analysis.

intestinal mucosa to adenoma (adenomatous mucosa) and finally to adenocarcinoma in CRC is closely correlated with the EMT process and changes in the expression of a series of genes, such as E-cadherin, vimentin, and $\beta$-catenin $[24,25]$. Thus, we further investigated whether CK2 $\alpha$ expression is associated with the EMT process. Interestingly, in our study, assays of EMTrelated markers found that $\mathrm{CK} 2 \alpha$ knockdown or activity inhibition can alter the expression of E-cadherin and vimentin and reverse the EGF-induced cytoplasmic-tonuclear translocation of $\beta$-catenin. We confirmed that CK $2 \alpha$ modulates the process of EMT, thereby affecting 

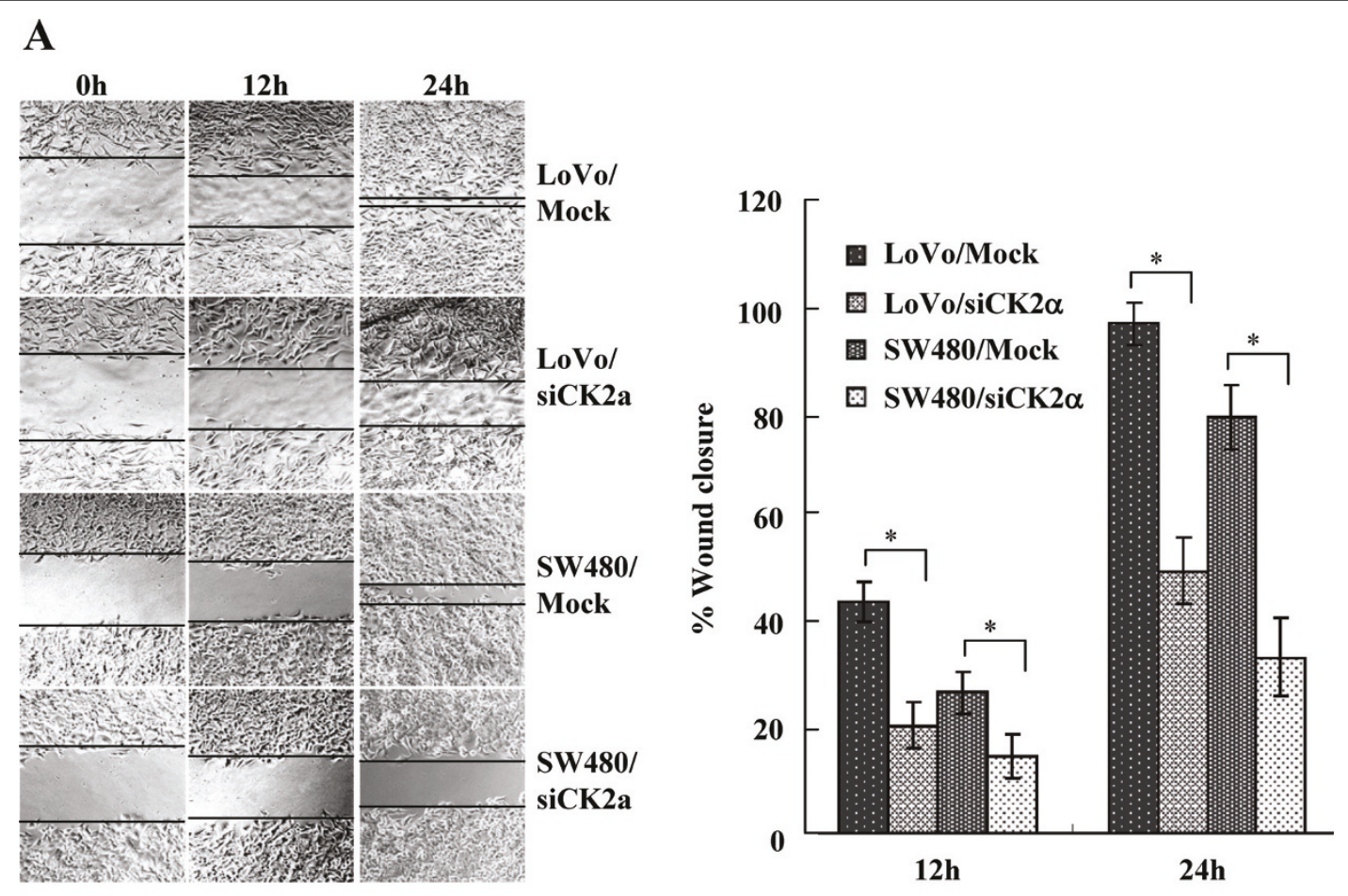

B

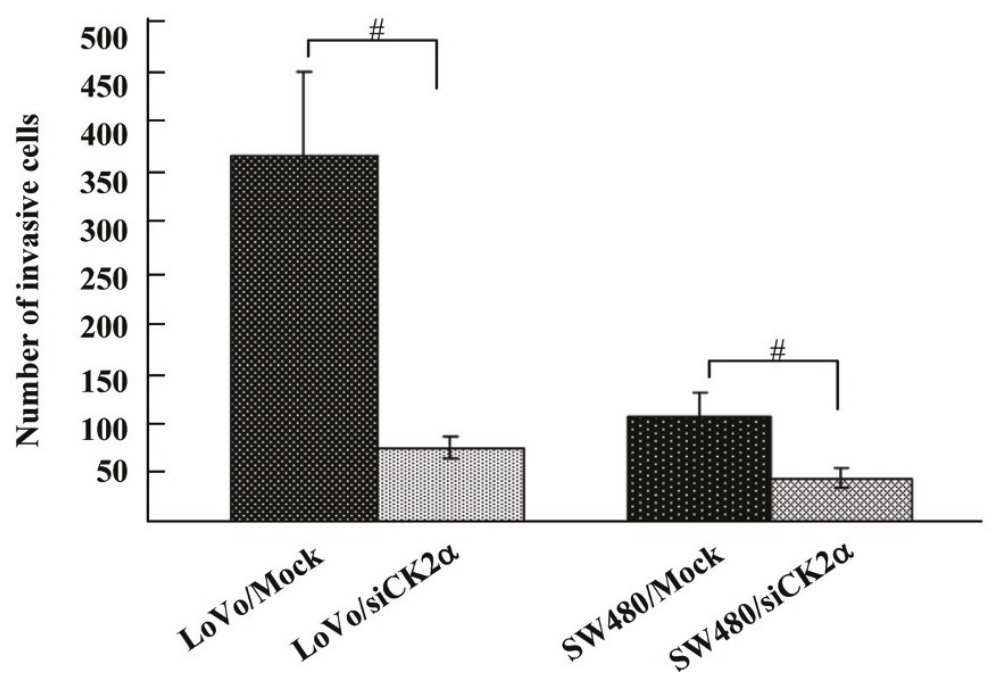

Figure 5 Knockdown of CK2 $\alpha$ inhibited cell migration and invasion of CRC cell lines. (A) Monolayers of cells transfected with CK2 $\alpha$-specific siRNAs were wounded by scraping, and wound closure was followed at 0, 12, and $24 \mathrm{~h}$. The distance of the wound was measured. Columns, mean of three independent experiments; bars, SD. ${ }^{*} P<0.01$. (B) After transfection with CK2 $\alpha$-specific siRNAs for $18 \mathrm{~h}$, cells that migrated through the filters were counted in five randomly selected fields. Columns, mean of three independent experiments; bars, SD. \#P<0.05.

the regulation of cell migration and invasion by colorectal cancer cells. Snail1 and Smad2/3 are important transcriptional regulators of EMT that repress E-cadherin expression through binding to E-box motifs (5'CANNTG-3') in the promoter [26-28]. In our study, we found that CK2 $\alpha$ knockdown decreases the expressions of snail 1 and smad2/3. It is clearly shown that downregulation of snail 1 and smad $2 / 3$ by $C K 2 \alpha$ knockdown facilitates an increase in E-cadherin expression and EMT repression. Previous studies found that, in Her-2/ neu-driven mammary tumor cells, CK2 may be involved in EMT repression, which can be induced by green tea 
A
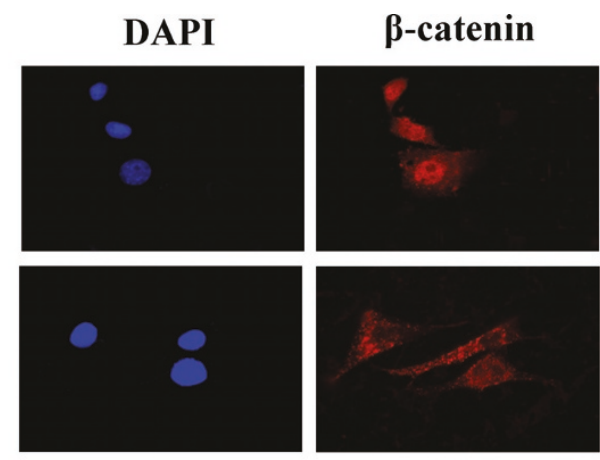

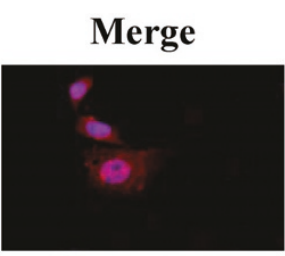

LoVo

/Mock

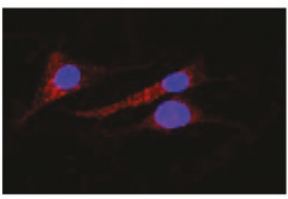

LoVo

$/ \mathrm{siCK} 2 \alpha$
B

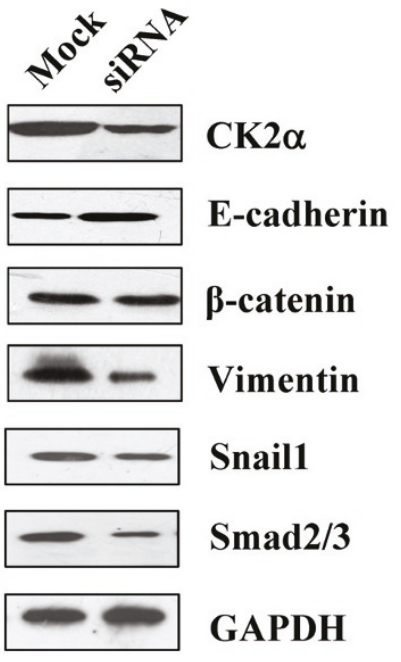

C
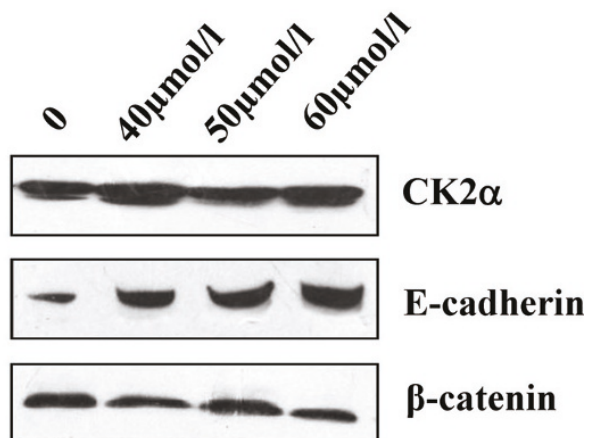

B-catenin

Vimentin

GAPDH

Figure 6 Inhibition of $\mathrm{CK} 2 \alpha$ reversed the nuclear translocation of $\beta$-catenin and altered EMT-related genes expression. Reversal of EGFinduced nuclear translocation of $\beta$-catenin occurred in LoVo cells transfected with CK2 $\alpha$-specific siRNA (A), treated with EGF (100 ng/ml) for 2 h, and stained for immunofluorescence with $\beta$-catenin antibody (red) and DAPI (blue). (B) Western blot was used to detect the expression levels of CK2 $\alpha$, E-cadherin, $\beta$-catenin, vimentin and the transcription factors snail 1 and smad2/3 in cells transfected with CK2 $\alpha$-specific siRNA. (C) One week later, in LoVo cells treated with emodin $(40 \mu \mathrm{mol} / \mathrm{l}, 50 \mu \mathrm{mol} / \mathrm{l}$ and $60 \mu \mathrm{mol} / \mathrm{l})$, the expressions of E-cadherin, $\beta$-catenin and vimentin were detected by western blot analysis. GAPDH expression was used as a loading control.

polyphenol epigallocatechin-3-gallate (EGCG) [29]. In untransformed mammary epithelial cells, ectopic expression of CK2 $\alpha$ facilitates the induction of EMT-related genes expression, such as that of Slug and AhR, which may thus promote the process of EMT [30]. Here we show for the first time that, in CRC, CK $2 \alpha$ modulates the EMT process through regulating the location or expression of EMT-related genes. Recent studies have indicated that, in breast cancer, p53/p21 and C-myc not only regulate growth and senescence but are also involved in regulating the EMT process [31-34]. Thus, we inferred that, in CRC, alteration of p53/p21 and Cmyc expression by CK2 $\alpha$ knockdown may facilitate the EMT repression observed in our study. These findings may account in part for the association of CK2 $\alpha$ overexpression with EMT in colorectal cancer. Additional studies are required to clarify the involvement of CK2 $\alpha$ in EMT and the development of colorectal cancer.

\section{Conclusions}

Our study demonstrates that CK2 $\alpha$ is overexpressed in CRC and that CK2 $\alpha$ expression is much greater in CRC than in adenoma and is greater in adenoma than in normal colorectal epithelium. Moreover, it is noteworthy to observe that, for the first time, overexpression of CK2 $\alpha$ seems to be involved in the carcinogenesis and development of CRC through regulation of EMT-related genes. CK2 $\alpha$ may be a promising molecular target for the diagnosis and treatment of human CRC.

\section{Acknowledgements}

This work was supported by the Natural Science Foundation of Guangdong Province, China (No. 10151051501000062).

\section{Author details}

${ }^{1}$ Department of Radiation Oncology, Nanfang Hospital, Southern Medical University, Guangzhou 510515, Guangdong Province, China. ${ }^{2}$ Hepatology 
Unit and Department of Infectious Diseases, Nanfang Hospital, Southern Medical University, Guangzhou 510515, Guangdong Province, China.

\section{Authors' contributions}

$J Z, H L, Z D$, and QZ designed and performed experiments. JZ and HL performed the statistical analysis and drafted the manuscript. DW and $\mathrm{LL}$ helped in drafting the manuscript and contributed specific information and critical analysis throughout the manuscript. All authors read and approved the final manuscript.

\section{Competing interests}

The authors declare that they have no competing interests.

Received: 26 February 2011 Accepted: 25 June 2011

Published: 25 June 2011

\section{References}

1. Jemal A, Siegel R, Ward E, Hao Y, Xu J, Murray T, Thun MJ: Cancer statistics, 2008. CA Cancer J Clin 2008, 58:71-96.

2. Sung JJ, Lau JY, Goh KL, Leung WK: Increasing incidence of colorectal cancer in Asia: implications for screening. Lancet Oncol 2005, 6:871-876.

3. Pino MS, Chung DC: The chromosomal instability pathway in colon cancer. Gastroenterology 138:2059-2072.

4. Boland CR, Goel A: Microsatellite instability in colorectal cancer. Gastroenterology 138:2073-2087, e2073.

5. Hadziavdic V, Pavlovic-Calic N, Eminovic I: Microsatellite instability and loss of heterozygosity of tumor suppressor genes in Bosnian patients with sporadic colorectal cancer. Bosn J Basic Med Sci 2008, 8:313-321.

6. Gocke CD, Benko FA, Kopreski MS, McGarrity TJ: p53 and APC mutations are detectable in the plasma and serum of patients with colorectal cancer (CRC) or adenomas. Ann N Y Acad Sci 2000, 906:44-50.

7. Derks S, Bosch $\amalg$, Niessen HE, Moerkerk PT, van den Bosch SM, Carvalho B, Mongera S, Voncken JW, Meijer GA, de Bruine AP, et al: Promoter CpG island hypermethylation- and $\mathrm{H} 3 \mathrm{~K} 9 \mathrm{me} 3$ and $\mathrm{H} 3 \mathrm{~K} 27$ me3-mediated epigenetic silencing targets the deleted in colon cancer (DCC) gene in colorectal carcinogenesis without affecting neighboring genes on chromosomal region 18q21. Carcinogenesis 2009, 30:1041-1048.

8. Toyota M, Ohe-Toyota M, Ahuja N, Issa JP: Distinct genetic profiles in colorectal tumors with or without the CpG island methylator phenotype. Proc Natl Acad Sci USA 2000, 97:710-715.

9. Litchfield DW: Protein kinase CK2: structure, regulation and role in cellular decisions of life and death. Biochem J 2003, 369:1-15.

10. Meggio F, Pinna LA: One-thousand-and-one substrates of protein kinase CK2? FASEB J 2003, 17:349-368.

11. Seldin DC, Lou DY, Toselli P, Landesman-Bollag E, Dominguez I: Gene targeting of CK2 catalytic subunits. Mol Cell Biochem 2008, 316:141-147.

12. Padmanabha $R$, Chen-Wu JL, Hanna DE, Glover CV: Isolation, sequencing, and disruption of the yeast CKA2 gene: casein kinase II is essential for viability in Saccharomyces cerevisiae. Mol Cell Biol 1990, 10:4089-4099.

13. Buchou $T$, Vernet $M$, Blond $O$, Jensen $H H$, Pointu $H$, Olsen BB, Cochet $C$ Issinger OG, Boldyreff B: Disruption of the regulatory beta subunit of protein kinase CK2 in mice leads to a cell-autonomous defect and early embryonic lethality. Mol Cell Biol 2003, 23:908-915.

14. Kulartz M, Hiller E, Kappes F, Pinna LA, Knippers R: Protein kinase CK2 phosphorylates the cell cycle regulatory protein Geminin. Biochem Biophys Res Commun 2004, 315:1011-1017.

15. Canton DA, Litchfield DW: The shape of things to come: an emerging role for protein kinase CK2 in the regulation of cell morphology and the cytoskeleton. Cell Signal 2006, 18:267-275.

16. Gu L, Husain-Ponnampalam R, Hoffmann-Benning S, Henry RW: The protein kinase CK2 phosphorylates SNAP190 to negatively regulate SNAPC DNA binding and human U6 transcription by RNA polymerase III. J Biol Chem 2007, 282:27887-27896

17. Guo C, Davis AT, Yu S, Tawfic S, Ahmed K: Role of protein kinase CK2 in phosphorylation nucleosomal proteins in relation to transcriptional activity. Mol Cell Biochem 1999, 191:135-142.

18. Ruzzene M, Pinna LA: Addiction to protein kinase CK2: a common denominator of diverse cancer cells? Biochim Biophys Acta 1804:499-504

19. Wu D, Ding $Y$, Wang S, Zhang $Q$, Liu L: Increased expression of high mobility group box 1 (HMGB1) is associated with progression and poor prognosis in human nasopharyngeal carcinoma. J Pathol 2008, 216:167-175

20. Masunaga R, Kohno H, Dhar DK, Ohno S, Shibakita M, Kinugasa S, Yoshimura H, Tachibana M, Kubota H, Nagasue N: Cyclooxygenase-2 expression correlates with tumor neovascularization and prognosis in human colorectal carcinoma patients. Clin Cancer Res 2000, 6:4064-4068.

21. Lin KY, Tai C, Hsu JC, Li CF, Fang CL, Lai HC, Hseu YC, Lin YF, Uen YH: Overexpression of nuclear protein kinase CK2 alpha catalytic subunit (CK2alpha) as a poor prognosticator in human colorectal cancer. PLoS One 6:e17193.

22. Ahmad KA, Harris NH, Johnson AD, Lindvall HC, Wang G, Ahmed K: Protein kinase CK2 modulates apoptosis induced by resveratrol and epigallocatechin-3-gallate in prostate cancer cells. Mol Cancer Ther 2007, 6:1006-1012.

23. Brown MS, Diallo OT, Hu M, Ehsanian R, Yang X, Arun P, Lu H, Korman V, Unger G, Ahmed K, et al: CK2 modulation of NF-kappaB, TP53, and the malignant phenotype in head and neck cancer by anti-CK2 oligonucleotides in vitro or in vivo via sub-50-nm nanocapsules. Clin Cancer Res 16:2295-2307.

24. Vincan E, Brabletz T, Faux MC, Ramsay RG: A human three-dimensional cell line model allows the study of dynamic and reversible epithelialmesenchymal and mesenchymal-epithelial transition that underpins colorectal carcinogenesis. Cells Tissues Organs 2007, 185:20-28.

25. Chen X, Halberg RB, Burch RP, Dove WF: Intestinal adenomagenesis involves core molecular signatures of the epithelial-mesenchymal transition. J Mol Histol 2008, 39:283-294.

26. Vincent $T$, Neve EP, Johnson JR, Kukalev A, Rojo F, Albanell J, Pietras K, Virtanen I, Philipson L, Leopold PL, et al: A SNAIL1-SMAD3/4 transcriptional repressor complex promotes TGF-beta mediated epithelial-mesenchymal transition. Nat Cell Biol 2009, 11:943-950.

27. Phanish MK, Wahab NA, Colville-Nash P, Hendry BM, Dockrell ME: The differential role of Smad2 and Smad3 in the regulation of pro-fibrotic TGFbeta1 responses in human proximal-tubule epithelial cells. Biochem J 2006, 393:601-607.

28. Nawshad A, Medici D, Liu CC, Hay ED: TGFbeta3 inhibits E-cadherin gene expression in palate medial-edge epithelial cells through a Smad2Smad4-LEF1 transcription complex. J Cell Sci 2007, 120:1646-1653.

29. Belquise K, Guo S, Sonenshein GE: Activation of FOXO3a by the green tea polyphenol epigallocatechin-3-gallate induces estrogen receptor alpha expression reversing invasive phenotype of breast cancer cells. Cancer Res 2007, 67:5763-5770.

30. Belguise K, Guo S, Yang S, Rogers AE, Seldin DC, Sherr DH, Sonenshein GE: Green tea polyphenols reverse cooperation between c-Rel and CK2 that induces the aryl hydrocarbon receptor, slug, and an invasive phenotype. Cancer Res 2007, 67:11742-11750.

31. Kim T, Veronese A, Pichiorri F, Lee TJ, Jeon YJ, Volinia S, Pineau P, Marchio A, Palatini J, Suh SS, et al: p53 regulates epithelial-mesenchymal transition through microRNAs targeting ZEB1 and ZEB2. J Exp Med 208:875-883.

32. Schubert J, Brabletz T: p53 spreads out further: suppression of EMT and stemness by activating miR-200c expression. Cell Res 21:705-707.

33. Cho KB, Cho MK, Lee WY, Kang KW: Overexpression of c-myc induces epithelial mesenchymal transition in mammary epithelial cells. Cancer Lett 293:230-239.

34. Liu M, Casimiro MC, Wang C, Shirley LA, Jiao X, Katiyar S, Ju X, Li Z, Yu Z, Zhou J, et al: p21CIP1 attenuates Ras- and c-Myc-dependent breast tumor epithelial mesenchymal transition and cancer stem cell-like gene expression in vivo. Proc Natl Acad Sci USA 2009, 106:19035-19039.

doi:10.1186/1479-5876-9-97

Cite this article as: Zou et al:: Protein kinase CK2 $\alpha$ is overexpressed in colorectal cancer and modulates cell proliferation and invasion via regulating EMT-related genes. Journal of Translational Medicine 2011 9:97. 